\title{
Ensino de física por investigação: uma proposta de sequência investigativa para o ensino de calorimetria
}

\author{
Ronilson da Silva Lima ${ }^{1}$, Jorge Luis López Aguilar², Bianca Martins Santos ${ }^{3}$ e Isaías Fernandes Gomes ${ }^{4}$ \\ 1, 2, 3, 4 Universidade Federal do Acre
}

Palavras-Chave: Ensino de física; Sequência investigativa; Calorimetria.

\section{Introdução}

No que tange o ensino de física é um desafio ensinar com virtuosidade essa área de conhecimento do ensino médio. Os docentes precisam encarar a aversão dos alunos concernente a disciplina ou o conteúdo a ser trabalhado, acarretado pela falta de conectividade do assunto à realidade do aprendiz, agregando uma desmotivação e desinteresse suscitado pela imagem que física é difícil e não se aplica no cotidiano. Para tanto, em meio a essa realidade condizente ao ensino-aprendizagem de física, esse trabalho apresenta uma proposta metodológica através de Sequências de Ensino Investigativas - SEl, pois de acordo com Carvalho (2013), além de sistematizarem importantes resultados das pesquisas em ensino de física, trazem algumas referências essenciais para aulas mais interessantes e motivadoras para os discentes e docentes, de tal modo, essa proposta é referente ao conteúdo de calorimetria, onde objetiva-se contribuir para melhoria do referido ensino.

Uma SEI difere de uma sequência tradicional que segue um roteiro predefinido com a qual se pode comprovar ou visualizar determinado conteúdo, pois inicia-se a abordagem do conteúdo a partir de uma situação problematizadora, podendo ser um problema aberto, assim os alunos serão levados a elaborarem estratégias de resolução por meio de levantamento de hipóteses, a raciocinar sobre a relevância e coerência de determinadas variáveis na resolução do problema, justificar suas escolhas e buscar a linguagem cientifica e matemática adequada, além disso, nesse tipo de trabalho o aluno desenvolve autonomia de pensamento. Tais características são análogas ao trabalho cientifico desenvolvido pelos cientistas, onde os discentes podem construir um melhor entendimento em relação a atividade cientifica e sua natureza possibilitando um ensino cujo construção do conhecimento ultrapasse as leis, teorias e fórmulas, tantas remetidas ao ensino tradicional de física. Nesse sentido, sobre as SEls, Fernandez (2012) indica algumas habilidades que os alunos podem desenvolverem nessas atividades, tais como: observar, descrever, comparar, analisar, discutir, criar hipóteses, teorizar, questionar, argumentar, atuar com procedimentos, avaliar, decidir, concluir, generalizar, divulgar, escrever e dissertar.

Desse modo, esse trabalho apresenta três propostas de atividades investigativas, com o intuito de utilizar a sequência para dinamizar a aula, despertar o interesse dos alunos a partir da participação ativa na aula, descontruir conceitos errôneos sobre o conteúdo e entusiasmar os educandos em construir a própria aprendizagem através da prática investigativa.

\section{Metodologia}

São propostas três experiências sobre calorimetria: $1^{a}$ ) $O$ tato nos fornece a temperatura ou a sensação térmica de um corpo?; $2^{a}$ ) Haste de madeira versus haste de ferro; e $3^{\text {a }}$ ) A diferenciação entre calor e temperatura. No $1^{\circ}$ experimento, objetiva-se verificar que não é seguro medir a temperatura de determinado corpo através do tato, reconhecendo que a temperatura é uma medida da sensação de quente ou frio, isto em relação a determinado padrão e reconhecer que os instrumentos de medida de temperatura como o termômetro levam um tempo para entrarem em equilíbrio térmico com o sistema, o qual deseja-se obter valor de forma correta. O 20 experimento tem por finalidade demonstrar que, na maioria dos casos, as percepções táteis não funcionam corretamente para determinar a temperatura de um sistema. E a partir do 3ํe experimento objetivase demonstrar a diferença entre temperatura e calor.

Para realização dessa atividade é proposto que o professor antes de iniciar a atividade, submeta aos aprendizes, questionários como ferramenta para absorção dos conhecimentos prévios. $\mathrm{Na}$

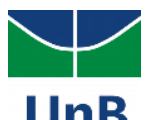


realização da prática, o docente irá organizar a turma em grupos de 4 à 5 pessoas, em seguida é proposto uma situação problematizadora, que levará aos discentes formularem hipóteses sobre as possíveis resoluções para o problema. Após, será aplicado o experimento cujo sua realização, é a solução do problema. Posteriormente, todos os grupos irão se reunir e apresentar os resultados e a solução para a situação inicial, por fim, por intermédio do professor os grupos irão medir os valores reais do experimento e no coletivo chegaram na resolução da pergunta que originou o experimento.

Com caráter qualitativo, o trabalho inclui o levantamento bibliográfico de obras relacionadas sobre a aplicação de atividades experimentais para o ensino de física, especificamente para alunos do $2^{\circ}$ ano do ensino médio. O trabalho baseia-se na teoria da aprendizagem significativa, que de acordo com Ausubel (1973), o professor deve identificar um conteúdo relevante na estrutura cognitiva do estudante e fazer uso desse conteúdo para a aprendizagem do novo material. Nesse caso o professor pode fazer relações entre conteúdos novos e conteúdos velhos. Desta forma, o professor irá submeter os alunos a pré-testes por meio de questionários a fim de averiguar os conhecimentos prévios dos discentes, mesmo que seja em uma abordagem não cientifica e ao término de toda prática investigativa o professor submeterá aos discentes novamente a outro questionário, o pós-teste. Conjuntamente a proposta é baseada na teoria de Vygotsky, pois, como afirma De Andrade; et. al. (2003), a atividade será realizada em grupos, objetivando-se o sóciointeracionismo entre os alunos na prática, suscitando assim, em uma aprendizagem mútua alcançando, portanto, a zona de desenvolvimento proximal (ZDP).

\section{Resultados esperados}

A partir da aplicação dessa prática experimental, espera-se que os alunos envolvidos na aula absorvam o máximo de conteúdo possível, acarretando desta forma, facilitar o processo de ensino aprendizagem, isto, oriundo de uma motivação, entusiasmo, e interesse, pois através das práticas investigativas gerará nos discentes uma curiosidade e um desafio a ser solucionado em frente a situação problematizadora. Os alunos não podem serem somente espectadores das realizações experimentais, mas um participante ativo, pois de acordo com Delizoicov; et. al. (2009), isso implica tornar a aprendizagem dos conhecimentos científicos em sala de aula num desafio prazeroso e conseguir que seja significativa para todos, tanto para professores quanto para alunos.

Portanto, a abordagem experimental de física dentro do ensino médio pode romper barreiras atribuídas muitas vezes pela fadiga. O professor precisa de alguma forma prender a atenção dos alunos e agregar conhecimento, assim o trabalho propõe atividades investigativas, cujo os alunos possam estabelecer uma ligação entre a teoria e a prática, desenvolvendo uma série de habilidade de cognição, pois ele estará sendo o construtor de próprio conhecimento, despertando o interesse dos estudantes pela ciência.

\section{Referências}

\section{AUSUBEL, D. P. Algunos aspectos psicológicos de la estrutuctura del conocimiento.} Buenos Aires: El Ateneo, 1973.

CARVALHO, A. M. P. O ensino de ciências e a proposição de sequências de ensino investigativas. In: CARVALHO, A. M. P. (Org.) Ensino de ciências por investigação - Condições para implementação em sala de aula. São Paulo: Cengage Learning, 2013.

DE ANDRADE, A. F.; GIRAFFA, L. M. M.; VICARI, R. M. Uma Aplicação da Teoria Sociointeracionista de Vygotsky para construção de um Modelo de Aluno. In: Brazilian Symposium on Computers in Education (Simpósio Brasileiro de Informática na EducaçãoSBIE). 2003.

DELIZOICOV, D.; ANGOTTI, J. A.; PERNAMBUCO, M. M. Ensino de Ciências fundamentos e métodos. 3. ed. São Paulo: Cortez, 2009.

FERNANDEZ, S. S. Uma Proposta de atividades investigativas envolvendo sistema métrico. 2012. 97f. Dissertação (Mestrado em Ensino de Física) - Instituto de Física, Universidade Federal do Rio de Janeiro, Rio de Janeiro, 2012. 